ORIGINAL ARTICLE

\title{
Big Five personality traits among Polish students facing the transformations of the education system
}

\author{
Sara Filipiak (D) $1 \cdot A, B, C, D, E, F$, Beata Eubianka (D) $2 \cdot A, B, C, D, E, F$ \\ 1: Institute of Psychology, Faculty of Education and Psychology, Maria Curie-Skłodowska University, Lublin, Poland \\ 2: Department of Psychology, Institute of Pedagogy and Psychology, Jan Kochanowski University, Kielce, Poland
}

BACKGROUND

The aim of the present study was to analyze personality traits in the Big Five Model among Polish students in early adolescence, who were on the verge of introduction of a new reform in the Polish education system. The article presents a summary of the results of the first of the planned three stages of the longitudinal study.

\section{PARTICIPANTS AND PROCEDURE}

The participants of the study were 910 people at the sixth grade of primary schools, aged from 11 to $13(M=12.40$, $S D=0.58)$, and at the first grade of junior high schools, aged from 12 to $14(M=13.40, S D=0.53)$ in the school year 2016/2017. The analysis of personality traits was carried out using the Picture Based Personality Survey for Children (PBPS-C v1).

\section{RESULTS}

The results showed that young people from primary schools are more conscientious and open to experience than their older schoolmates. Girls from primary schools are more conscientious and open to new experience than their older peers; and boys from primary schools are more conscientious than their older schoolmates. Gender and level of education turned out to be significant predictors of some personality traits. Extraversion is associated with boys while neuroticism and agreeableness are associated with girls. Level of education is associated with openness to experience and conscientiousness.

\section{CONCLUSIONS}

The results are discussed in the context of possible practical rearing influence aimed at supporting young people's development in the context of educational changes that they are about to face.

\section{KEY WORDS}

personality; the Big Five; early adolescence; levels of education

Corresponding Author - Sara Filipiak, Ph.D., Institute of Psychology, Faculty of Education and Psychology,

Maria Curie-Skłodowska University, 5 Litewski Square, 20-080 Lublin, Poland, e-mail: s.filipiak@poczta.umcs.lublin.pl Authors' CONTRibution - A: Study design - B: Data collection - C: Statistical analysis · D: Data interpretation .

E: Manuscript preparation · F: Literature search · G: Funds collection

TO CITE THIS ARTICLE - Filipiak, S., \& Łubianka, B. (2019). Big Five personality traits among Polish students facing the

transformations of the education system. Current Issues in Personality Psychology, 7(2), 98-108.

RECEIVED 14.02.2019 - REVIEWED 29.04.2019 • ACCEPTED 06.05.2019 · PUBLISHED 31.05.2019 


\section{BACKGROUND}

The aim of the study was to analyze personality traits in Polish students in the phase of early adolescence. This period includes ages from 11/12 to 14/15 years (Obuchowska, 2006, 2009). When this study was conducted in the school year 2015/2016, these students were at the sixth grade of primary schools and at the first grade of junior high schools. The study was carried out while preparations for transformations of the education system in Poland were being made. Surveyed students knew that in the near future they would experience a change in the way their education is organized. As argued by Strelau (2000), each change, including the one that is connected with waiting for it, might be a source of stress. For students, learning itself, the educational environment - schoolmates, teachers, and also new requirements steaming from reformed education regulations, might all be a source of stress (Lewicka-Zelent \& Trojanowska, 2018). The augmented level of anxiety in students in the last classes of primary schools and in junior high schools, due to excessive demands, has already been raised in educational psychology research (Lewicka-Zelent \& Trojanowska, 2018; Tomaszek \& Muchacka-Cymerman, 2018). In the case of sixth grade students, a change of the education level implies, first and foremost, the necessity of meeting new school requirements connected with implementation of the new curriculum designed for new grades that are being introduced, that is, seventh and eighth. At the same time, junior high school students are aware that, as the last age group, they are finishing this type of higher school education. For these students the sole fact of junior high schools being transformed into primary schools and consequently the change in the name of their school, and introduction of seventh grade students who were not present in their school before, might be a source of stress.

As indicated in works available to date, the situation of an educational change might influence young people's personality development (Barani, 2006; Cantin \& Boivin, 2004; Dudzikowa \& Wawrzyniak-Beszterda, 2010; Kulas, 1996, 1998; Roberts \& Mroczek, 2008). Many factors influence the development of personality in early adolescence, including new experiences, a broadening scope of one's own activity, teaching and learning. Each change, including entering the new school environment and the necessity to face new educational demands, adopting to new peers and teachers, may be a source of stress for students (Lewicka-Zelent \& Trojanowska, 2018; Strelau, 2000). Social interactions are important underpinnings of personality development in early adolescence. Conflicting role demands and increasing complex relations with the opposite sex might be a source of their sense of uncertainty and anxiety (Barani, 2006; Block \& Robins, 1993; Kulas, 1998) or curiosity and a sense of self-efficacy (Piotrowski, Wojciechowska, \& Ziółkowska, 2014). Stéphane Cantin and Michel Boivin (2004) reported that children's perceived scholastic competences decreased after transition from elementary to junior high school. The moment of transition from a safe phase of childhood into adolescence may be initially a moment of confusion and bewilderment. Changes in self-image, the way how pupils think about themselves and the world have consequences in a sense of disorientation stemming from different expectations which are formulated towards them and their own expectations toward themselves (Piotrowski et al., 2014). It was reported that self-esteem is associated with quality of an adolescent's friendships (Keefe \& Berndt, 1996), body image (Williams \& Currie, 2000) and scholastic competences (Cantin $\&$ Boivin, 2004). Due to complex underpinnings of personality development, including the changes in the education process, this research was conducted. It was decided to compare personality traits measured using the Big Five Model in two groups of students from two different levels of education: the sixth grade of primary schools $(n=455)$ and the first grade of junior high schools $(n=455)$. In this article, the results of the first stage of longitudinal studies planned for the school years 2016-2019 are presented. The aim of the three-stage study plan is to characterize developmental changes of personality in young people who experience transformations of the education system in Poland (Baltes \& Lerner, 1980; Hornowska \& Paluchowski, 1991; Magnusson \& Bergman, 1990). Personality plays an important role in the prognosis of successful fulfillment of compulsory education duties, satisfactory interpersonal relations and future professional careers of young people (Asendorpf, Denissen, \& van Aken, 2008; Heaven \& Ciarrochi, 2012; Leung, 2008; Mendolia \& Walker, 2015). Personality is a set of traits that are manifested in the way one thinks, feels and behaves in everyday situations (Allemand \& Mehl, 2017; Roberts, 2007). This study fits into a trend of research which is gaining more and more popularity, namely, one regarding the personality of people entering the period of adolescence. Inclusion of young people taking part in the transformation of the education system in this study complements current knowledge regarding the significance of the influence that changes in the structure of education have upon developmental changes of personality in students during the period of early adolescence (Barani, 2006; Borghius et al., 2017; Kulas, 1996, 1998). Robert McCrae and Paul Costa (1997, 2003), the authors of the Five-Factor Model, define personality as a set of dynamically connected traits that are responsible for the ways of feeling, thinking and reacting. Personality enables one to predict how a person will behave in a given situation. The authors enumerate five personality traits: extraversion, neuroticism, conscientiousness, agreeableness 
and openness to experience (Costa \& McCrae, 1988, 1994; McCrae \& Costa, 1997). According to the concept of personality in the Big Five Model, traits are heritable, relatively stable during the course of life and culturally independent (Bourchard \& Loehin, 2001; Jansi \& Anbazhagan, 2017; McCrae \& Costa, 1996). Roberts and DelVecchio (2000) state that there is a linear relationship between chronological age and increase in the stability of human personality traits. The Five-Factor Model has been successfully verified in studies all around the world with subjects in different developmental periods (Baker, Victor, Chambers, \& Halverson, 2005; Cieciuch, 2010; Digman, 1997; Markey, Markey, \& Tinsley, 2018; McCrae \& Costa, 2003; Noftle \& Fleeson, 2010; Roberts, Wood, \& Caspi, 2008; Shimotsukasa, Oshio, Tani, \& Yamaki, 2019; Soto \& Tackett, 2015; Wortman, Lucas, \& Donnellan, 2012). Despite the fact that, until recently, the majority of studies on personality concerned adults (Luan, Hutteman, Denissen, Asendorpf, \& van Aken, 2017; Oleś, 2011), nowadays studies on developmental changes of personality traits in the period of adolescence in the Big Five Model are gaining more and more popularity (Branje, van Lieshout, \& Gerris, 2007; De Bolle et al., 2015; Pullmann, Raudsepp, \& Allik, 2006). The scarcity of studies on personality traits in the period of adolescence steamed mainly from the notion of lack of stability when it comes to traits in people who are growing up. Nevertheless, it is argued that the analysis of personality traits in the period of adolescence enables one to predict students' successes at school and in their future professional careers (Asendorpf et al., 2008). The development of personality in the period of early adolescence is connected with biological, emotional and social changes that a person experiences when growing up (Obuchowska, 2009). Early adolescence is the moment of moving from the period of childhood to the stage of human life in which they will be getting ready to enter the period of adulthood (Denissen, van Aken, Penke, \& Wood, 2013). Erickson (1968) calls this specific moment in a young person's life a psychological moratorium. Leaving the safe space of childhood and often encompassing fear of the unknown, trials of experimenting with new behaviors, might be a source of new experiences for young people. For those entering the period of growing up, trying oneself in new social roles might be a source of joy as well as stress (Kozina, 2017; Musiał, 2007). Young people learn to fulfill new tasks and roles that society puts in front of them. Taking up these roles and tasks is parallel to intensive changes in physiological functioning of a young organism. These changes influence the self-concept, including the sense of self-confidence and independence. The environment also influences young people's personality development. This includes the range of requirements at school connected with the change in the level of education (Dudzikowa
\& Wawrzyniak-Beszterda, 2010; Kulas, 1998; Roberts \& Mroczek, 2008). Personality development in early adolescence also depends on the individual experience of young persons. It describes their attitude towards surrounding reality, and shapes the habits and ways of interpreting different events.

Studies in the field of educational psychology show connections between personality traits in Big Five Model and young people's educational achievements (Bratko, Chamorro-Premuzic, \& Saks, 2006; Heaven \& Ciarrochi, 2012; John, Caspi, Robins, Moffit, \& Stouthamer-Loeber, 1994), quality of school adaptation (Barani, 2006; Graziano \& Ward, 1992) or life satisfaction (Marcionetti \& Rossier, 2016; Suldo, Minch, \& Hearon, 2015; Weber \& Huebner, 2015). Denis Bratko, Tomas Chamorro-Premuzic, and Zrnka Saks (2006) surveyed a group of Croatian teenagers aged from 15 to 18 and found that extraversion, neuroticism and conscientiousness proved to be better predictors of school achievements than intelligence. Based on research carried out on people in the period of early adolescence, William Graziano and David Ward (1992) showed that conscientiousness was a significant factor in successful school adaptation. Research also shows that a diagnosis of personality traits in the Big Five Model allows one to identify a potential group of young people with risk of self-destructive behaviors (Kotrla Topić, Perković Kovačević, \& Mlačić, 2012). In their research, Shannon Suldo, Devon Minch and Brittany Hearon (2015) showed that all traits of the Big Five proved to be significant predictors of life satisfaction among teenagers; at the same time, agreeableness was associated with life satisfaction in girls only. Similar conclusions were reached in research carried out by Marco Weber and Scott Huebner (2015) on 344 American teenagers in the period of early adolescence. Neuroticism was negatively associated with overall life satisfaction in the surveyed group of young people, whereas extraversion, agreeableness and conscientiousness were positively associated with it.

Analyses of personality traits in young people in longitudinal studies also provide interesting conclusions. Helle Pullmann, Liisa Raudsepp and Jüri Allik (2006) carried out a study on 2650 Estonian teenagers at the age of 12-18. The biggest developmental changes of personality traits were observed in the youngest group surveyed, between 12 and 14 years of age. During two years of studies, a significant increase in the level of extraversion was noted in girls, and also a decrease in the level of neuroticism and agreeableness in both boys and girls. Based on longitudinal studies on 285 Dutch teenagers, Susan Branje, Cornelis van Lieshout and Jan Gerris (2007) observed that in boys, extraversion and openness to experience decreased with age, whereas in girls, extraversion, agreeableness, conscientiousness and openness increased. 
Ziyan Luan, Roos Hutteman, Jaap Denissen, Jens Asendorpf and Marcel van Aken (2017) conducted analyses regarding young people's personality traits in longitudinal studies. The researchers took into account the self-description of 574 Dutch teenagers aged from 12 to 18 and descriptions of their personalities made by their parents. The results showed concurrence of the assessment regarding the level of neuroticism in students aged 12 made by both the students themselves and their parents. In the case of agreeableness, parents assessed their children as more agreeable then the students described themselves. Between the age of 12 and 17, agreeableness in students decreased according to their parents' assessment, and increased according to the students' opinion. Young people at the age of 12 described themselves as more conscientious when compared to the assessments made by their parents. These studies also showed high concurrence of assessments made by young people and those made by their parents in the case of extraversion. Parents also described their 12-year-old children as more open to experience than young people described themselves. In successive years, children's openness decreased according to their parents' opinion and it increased in young people's assessments. These studies indicate that it is justified to take into account different perspectives when assessing personality traits in people who are growing up. Studies on the Big Five Model with the participation of adolescents also show differences between boys and girls when it comes to personality traits. Based on longitudinal studies carried out in a group of 2230 Dutch teenagers aged from 12 to 22, Jeroen Borghuis and colleagues (2017) observed an increase in agreeableness with age in boys and girls, conscientiousness in the group of girls only, and increase of openness in boys.

\section{THE PRESENT STUDY}

The aim of this study was to analyze personality traits in the Big Five Model among Polish students in the period of early adolescence. The students attended the sixth grade of primary schools - the first year to fulfill the guidelines of the new reform in the education system implying prolongation of education at seventh and eighth grades, and the first grade of junior high schools - the last year that puts an end to junior high school education (Act of 14 December 2016, Law on School Education). Presented literature provided a background for formulating the following research questions:

1. What is the configuration of personality traits among students from two levels of education?

2. Does the level of education differentiate girls in terms of personality traits?

3. Does the level of education differentiate boys in terms of personality traits?
4. What is the relationship between personality traits, gender and level of education in the whole group of students?

Due to the fact that the surveyed students are the first year to experience the reform that is currently being introduced, it was decided to abandon formulation of hypotheses. It was assumed that the results will allow us to extend current knowledge regarding specificity of young people's personality traits in early adolescence, while taking into account two different levels of education.

\section{PARTICIPANTS AND PROCEDURE}

\section{PARTICIPANTS}

All in all, 910 participants took part in the study 455 students at the sixth grade of primary schools and 455 students at the first grade of junior high schools. The group of sixth grade students of primary schools was composed of participants aged from 11 to 13 ( $M=12.40, S D=0.58$; of whom $51.00 \%$ were girls). The group of the first grade of junior high schools was represented by participants aged from 12 to 14 ( $M=13.40, S D=0.53$; of whom $51.00 \%$ were girls). The study was carried out in Lublin, in 6 primary schools and 4 junior high schools, in the period from December 2016 to June 2017. The study was carried out in compliance with appropriate ethical principles with special consideration given to participants' anonymity and voluntary participation (Banyard \& Flanagan, 2011; Keehn, 1982). Parents gave written permission for their children to take part in the study. The study was carried during one meeting with each class.

\section{MEASURE}

The study of personality traits in the Big Five Model was carried out using the Picture Based Personality Survey for Children (PBPS-C v1) designed by Maćkiewicz and Cieciuch (2012; 2016). Currently in Poland there is a lack of tools to measure personality traits in students in the period of early adolescence based on the Big Five Model that is comparable to PBPS-C v1. In many European countries, there are different versions of this test which are successfully used in order to analyze personality traits of people in the period of late childhood and early adolescence - in Italy (Barbaranelli, Caprara, Rabasca, \& Pastorelli, 2003), Germany (Bleidorn \& Ostendorf, 2009), France (Olivier \& Herve, 2015), Greece (Kokkinos \& Markos, 2015) and Spain (Del Barrio, Carrasco, \& Holgado, 2006).

A picture-based method like PBPS-C v1 considers cognitive abilities of children in late childhood and in younger adolescents, in which the ability of abstract 
thinking has not fully developed yet. The PBPS-C v1 questionnaire is composed of 15 items. Each of them contains two pictures. There is a short description of a given situation placed above each pair of pictures, for example: "When it rains". The person surveyed reads the sentence and then chooses one of the pictures with the following instruction: "Think about how you most often behave in this kind of situation". The person surveyed is being instructed that they should consider whether in a given situation they more frequently behave like the character presented in the picture on the right or on the left. Then the subject indicates a square describing how much a given behavior is similar to his own. The response is indicated on a 5-level scale. The range of possible results is between 3 and 15 points. There are two versions of PBPS-C v1: for younger children at grades I-III of primary school and for older children at grades IV-VI of primary school. In this study, the second version of this questionnaire was used. According to Piaget's theory of cognitive development (2005), the period of early adolescence is the time of developmental changes of reasoning consisting of a systematic increase in the ability of abstract thinking. The final aim of this process is such a form of thinking that is utterly free of figurativeness. This more mature form of thinking enables solving hypothetical and verbal-conceptual problems. This kind of thinking also enables formulation of equivalent solutions to the same problem. Surveyed students are on the verge of entering the period of early adolescence, and for this reason the NEO-FFI questionnaire (Zawadzki, Strelau, Szczepaniak, \& Śliwińska, 1998), which might pose obstacles to understanding abstract descriptions of personality traits that are included in it, for at least some subjects, was abandoned. It was assumed that PBPS-C v1, due to its picture-based character, would be a more appropriate tool for measuring personality traits in the surveyed students in the first stage of the planned studies.

\section{RESULTS}

Quantitative interpretation of obtained data was carried out based on raw scores. Analyses of results are presented in the same order that the research questions were raised. In order to verify whether there are statistically significant differences between obtained results regarding personality traits in students from the two levels of education compared, the independent samples Student's $t$-test was used. The relationships between personality traits, gender and level of education were tested in a multiple regression model where gender and level of education were predictors and personality traits were dependent variables. Analyses of data obtained in the studies were carried out using SPSS Statistics Pack, version 24.

Data presented in Table 1 show that students from primary schools are characterized by significantly higher openness to experience and conscientiousness than their schoolmates from the first grade of junior high schools.

Data presented in Table 2 show significant differences between girls from primary schools and their schoolmates from junior high schools regarding openness to experience and conscientiousness. Girls from the sixth grade are more open to experience and are characterized by a higher level of conscientiousness.

Table 3 shows that boys from primary schools are characterized by higher conscientiousness compared with their peers from junior high schools.

Table 4 presents the results of a multiple regression analysis in which gender and level of education were predictors and personality traits were dependent variables. The regression model fits the data, as follows: extraversion $F(2,908)=5.11, p<.01$, neuroticism $F(2,908)=16.90, p<.001$, openness to experience $F(2,908)=3.37, p<.05$, conscientiousness $F(2,908)=8.00, p<.001$, and agreeableness

Table 1

Test of the significance of differences - Student's t-test - for the results of PBPS-C $v 1$ for all students of primary school and junior high school

\begin{tabular}{|c|c|c|c|c|c|}
\hline \multirow[t]{3}{*}{ Personality traits } & \multicolumn{4}{|c|}{ Level of education } & \multirow[t]{3}{*}{$t$} \\
\hline & \multicolumn{2}{|c|}{$\begin{array}{l}\text { Primary school } \\
\qquad n=455\end{array}$} & \multicolumn{2}{|c|}{$\begin{array}{l}\text { Junior high school } \\
\qquad n=455\end{array}$} & \\
\hline & $M$ & $S D$ & $M$ & $S D$ & \\
\hline Extraversion & 11.74 & 2.72 & 11.52 & 2.64 & 0.14 \\
\hline Neuroticism & 8.47 & 2.74 & 8.62 & 2.87 & -1.44 \\
\hline Openness to experience & 9.41 & 2.60 & 8.73 & 2.74 & $2.69^{* *}$ \\
\hline Conscientiousness & 10.03 & 2.71 & 9.35 & 2.83 & $3.93^{* * *}$ \\
\hline Agreeableness & 11.30 & 2.46 & 11.31 & 2.46 & -0.01 \\
\hline
\end{tabular}


$F(2,908)=3.30, p<.05$. The obtained regression coefficients allow us to conclude that personality traits that are related to gender are extraversion (positively) and neuroticism and agreeableness (negatively). These results suggest that extraversion is associated with boys while neuroticism and agreeableness are associated with girls. It should be noted that gender explains $1 \%$ of extraversion and agreeableness separatelely, and $4 \%$ of neuroticism. Meanwhile, personality traits linked with level of education are openness to experi-

Table 2

Test of the significance of differences - Student's t-test - for the results of PBPS-C v1 between girls of primary school and junior high school

\begin{tabular}{|c|c|c|c|c|c|}
\hline \multirow[t]{3}{*}{ Personality traits } & \multicolumn{4}{|c|}{ Girls } & \multirow[t]{3}{*}{$t$} \\
\hline & \multicolumn{2}{|c|}{$\begin{array}{c}\text { Primary school } \\
\quad n=232\end{array}$} & \multicolumn{2}{|c|}{$\begin{array}{l}\text { Junior high school } \\
\qquad n=210\end{array}$} & \\
\hline & $M$ & $S D$ & $M$ & $S D$ & \\
\hline Extraversion & 11.48 & 2.96 & 11.47 & 2.65 & 0.01 \\
\hline Neuroticism & 8.96 & 2.48 & 9.21 & 2.89 & -1.09 \\
\hline Openness to experience & 9.54 & 2.54 & 9.01 & 2.69 & $2.29^{* *}$ \\
\hline Conscientiousness & 9.92 & 2.64 & 9.23 & 2.65 & $2.87^{* *}$ \\
\hline Agreeableness & 11.50 & 2.45 & 11.42 & 2.46 & 0.32 \\
\hline
\end{tabular}

Table 3

Test of the significance of differences - Student's t-test - for the results of PBPS-C $v 1$ between boys of primary school and junior high school

\begin{tabular}{|c|c|c|c|c|c|}
\hline \multirow[t]{3}{*}{ Personality traits } & \multicolumn{4}{|c|}{ Boys } & \multirow[t]{3}{*}{$t$} \\
\hline & \multicolumn{2}{|c|}{$\begin{array}{c}\text { Primary school } \\
\qquad n=223\end{array}$} & \multicolumn{2}{|c|}{$\begin{array}{l}\text { Junior high school } \\
\qquad n=245\end{array}$} & \\
\hline & $M$ & $S D$ & $M$ & $S D$ & \\
\hline Extraversion & 12.02 & 2.43 & 11.95 & 2.63 & 0.24 \\
\hline Neuroticism & 7.95 & 2.90 & 8.14 & 2.78 & -1.09 \\
\hline Openness to experience & 9.28 & 2.67 & 8.83 & 2.83 & 1.52 \\
\hline Conscientiousness & 10.14 & 2.75 & 9.43 & 2.93 & $2.70^{* *}$ \\
\hline Agreeableness & 11.10 & 2.45 & 11.21 & 2.44 & -0.36 \\
\hline
\end{tabular}

Table 4

Results of regression analysis with gender and level of education as predictors and personality traits as dependent variable

\begin{tabular}{|c|c|c|c|c|c|c|c|c|}
\hline \multirow[t]{2}{*}{ Personality traits } & \multicolumn{3}{|c|}{ Gender } & \multicolumn{3}{|c|}{ Level of education } & \multirow[t]{2}{*}{$R^{2}$} & \multirow[t]{2}{*}{ Adj $R$} \\
\hline & $\beta$ & $S E$ & $t$ & $\beta$ & $S E$ & $t$ & & \\
\hline Extraversion & .11 & .09 & $3.19^{* * *}$ & .01 & .18 & 0.15 & .01 & .01 \\
\hline Neuroticism & -.18 & .09 & $-5.65^{* * *}$ & .04 & .18 & 1.41 & .04 & .03 \\
\hline Openness to experience & -.05 & .09 & -1.43 & -.07 & .18 & $-2.16^{*}$ & .01 & .01 \\
\hline Conscientiousness & .04 & .09 & 1.27 & -.13 & .18 & $-3.79^{* * *}$ & .02 & .01 \\
\hline Agreeableness & -.07 & .08 & $-2.22^{*}$ & .01 & .16 & 0.43 & .01 & .01 \\
\hline
\end{tabular}


ence and conscientiousness and it is a negative relationship. These results show that these traits are more typical for students in primary schools, although the level of education explains only $1 \%$ of openness to experience and $2 \%$ of conscientiousness. Summing up, these results indicate on a significant, but weak relationship between personality traits, gender and level of education. The tested model explains a low percentage of variation of each personality trait.

\section{DISCUSSION}

The aim of this study was to determine the configuration of personality traits in students in the period of early adolescence, who are on the verge of transformations of the education system in Poland. Young people attended two levels of education: primary school and junior high school. It was also decided to examine how level of education differentiates personality traits in groups of boys and girls separately. It was also tested whether there are relationships between gender, level of education and personality traits. Due to the unique moment of carrying out this study - preparations for introduction of education reform - and awareness that this situation might have a direct influence on personality of the students surveyed, formulation of hypotheses was abandoned.

The results of the conducted study indicate that both boys and girls from primary schools are more conscientious and open to experience than their peers from junior high school. Analyses that take into account students' gender showed that girls in primary schools are more conscientious and open to experience than their older schoolmates from junior high schools, and boys from primary schools are more conscientious than their older colleagues. It is worth mentioning that the difference in age among the students in primary and junior high schools was only one year. It is proved that not chronological age itself but new experiences, social demands and requirements are the sources of developmental changes of personality (Pedersen \& Reynolds, 2002; Siegler, 1998). Therefore, level of education might be considered as important factor differentiating personality traits in the young people surveyed. Further analysis gave some more information concerning the significance of gender and level of education as important factors influencing the development of personality in early adolescence. The analyses showed that both gender and level of education are predictors of some personality traits. Extraversion is associated with boys while neuroticism and agreeableness are associated with girls. It should be noted, however, that although gender is a significant predictor of these personality traits, it has limited connections with them. This result partially confirms the results of De Bolle et al. (2015) revealing that girls in early adolescence scored higher in neuroticism than boys. The results also revealed that openness to experience and conscientiousness are related to the level of education. Students in primary schools are more open to new challenges and are more diligent than their older peers. However, the relationship between the level of education and these features is low. When it comes to students at first grades of junior high schools, they are less open to change compared to their peers from primary schools. Probably it is because they are experiencing a sense of novelty in a new school, environment and demands. It is documented in the literature that openness to experience combines with experiencing both positive and negative emotions, depending on the situational context (DeNeve \& Cooper, 1998). The new situation that students find themselves in requires re-organization of their resources in order for them to adjust to what is new and unknown - to what they are currently experiencing independently of their own will. It might be presumed that the sense of stabilization, which should be increasing in students at first grades of junior high schools, will cause an increase in openness to changes as they will be getting used to new requirements. This hypothesis will be verified in two further stages of the study planned.

Higher conscientiousness in students, both boys and girls, in primary schools can be explained by the fact that they are used to fulfilling well-known duties that were required from them during six years of education in the same educational environment. On the other hand, the change of educational environment in the case of students from the first grade of junior high schools and the necessity of adapting to new duties, which is linked to this change, made this group of young people face new challenges. It does not necessarily promote conscientiousness, as these students are only getting familiar with duties that they are supposed to fulfill. They are also busy finding their place in a new peer group, which is very important for their appropriate further psychosocial development (Smetana, Campione-Barr, \& Metzger, 2006; Tomé, Gaspar de Matos, Simões, Camacho, \& Alves Diniz, 2012a, 2012b). Probably it is only when students are sure of the requirements that they are expected to meet, they accept them and feel safe among their peers, that they will see the need for conscientious and patient fulfillment of new duties. It is worth bearing in mind that quantity and quality overload that is connected with the requirements that junior high school students are expected to meet is the primary source of stress for them. As shown in a study by Stanisław Korczyński (2014), the main source of stress for junior high school students is an excessive number of tasks to fulfill in the course of schooling and situations in which their knowledge is being tested.

It is difficult to compare the results obtained in this study with results obtained by other authors. 
Up to now, there has been no psychological research concerning analysis of personality traits in students on the verge of transformations of the education system in Poland. In order to fully explain the course of developmental changes of young people's personality, one needs to consider complex conditions, including those connected with change of social roles and requirements put in front of young people (Blakemore, 2008; Borghuis et al., 2017; Koepke \& Denissen, 2012). This postulate becomes particularly meaningful in a situation of education changes experienced by present-day Polish youth. It suggests that in the immediate future, these students will be especially susceptible to rearing influence. They are building their own identity through questioning, changing and seeking role models and different patterns of behavior (Obuchowska, 2009). For this reason, it is worth accompanying students in their individual choices and becoming their support and help. The results obtained in this study might help in widening the range of existing educational programs addressed to young people concerning, among other things, discovering and strengthening personal resources necessary in successful reduction of stress and constructive expression of one's emotions in difficult situations. They might also become a prerequisite for enrichment of the forms of work addressed to young people in subsequent years. It is worth mentioning that schools which took part in this study received feedback in the form of a report which contained a description of students' personality traits and hints on care and education of young people. Supporting traits associated with perseverance and patience during work and openness to new experience and change in students of primary schools is a justified action. These traits are the basis for cognitive curiosity and development of interests in young people. It is worth helping students from junior high school in adaptation to new requirements and to show them the benefits of conscientiously fulfilling duties which will be the basis of academic successes and a future professional career. It is also important to pay attention to integration training. It is documented that relationship building interventions in schools promote the development of social competences that are indispensable in building satisfying relations with peers, decreased antisocial behaviors, positive self-esteem, higher school commitment and academic achievement (Buhrmeister, 1990; Catalano et al., 2003; Miller et al., 2017).

In this article, the authors presented only the results from the first stage of a longitudinal study. Analyses concerned only comparisons of personality traits in two groups of students. The authors are aware of shortcomings stemming from the crosssectional study presented in this article, that is to say, comparisons between primary and junior high school students. However, the main idea of the whole research also encompasses other variables, such as personal values and locus of control due to the fact that they are susceptible to developmental changes in preadolescence. The development of these 3 variables will be tracked during a 3-year education period in a longitudinal strategy of research. At present, the second stage of research has been completed. After the third stage of the study, it will be possible to characterize the pattern of development of these variables in young people with the age range 12-15. It will also be possible to find relationships between them with regard to gender of the participants and two different levels of education.

\section{REFERENCES}

Act of 14 December 2016, Law on School Education [Ustawa z dnia 14 grudnia 2016 r. Prawo oświatowe. Dziennik Ustaw 2017, poz. 59].

Allemand, M., \& Mehl, M. R. (2017). Personality assessment in daily life. In J. Specht (Ed.), Personality development across the lifespan (pp. 437-454). San Diego: Elsevier.

Asendorpf, J. B., Denissen, J. J. A., \& van Aken, M. A. G. (2008). Inhibited and aggressive preschool children at 23 years of age: Personality and social transitions into adulthood. Developmental Psychology, 44, 997-1011.

Baker, S. R., Victor, J. B., Chambers A. L., \& Halverson, C. F. (2005). Adolescent personality. A fivefactor model construct validation. Assessment, 11, 303-315.

Baltes, M. M., \& Lerner R. M. (1980). Roles of the operant model and its methods in the life-span approach to human development. Human Development, 23, 362-367.

Banyard, P., \& Flanagan, C. (2011). Ethical issues in psychology. New York: Routledge.

Barani, K. (2006). Poczucie umiejscowienia kontroli a styl adaptacji w pierwszej klasie gimnazjum [Locus of control and adaptation style in first grade of junior high school]. Psychologia Rozwojowa, 11, 123-133.

Barbaranelli, C., Caprara, G. V., Rabasca, A., \& Pastorelli, C. (2003). A questionnaire for measuring the Big Five in late childhood. Personality and Individual Differences, 34, 645-664.

Blakemore, S. (2008). The social brain in adolescence. Nature Reviews. Neuroscience, 9, 267-277.

Bleidorn, W., \& Ostendorf, F. (2009). Ein Big FiveInventar für kinder und jungendliche [A Big Five inventory for children and adolescents]. Diagnostica, 55, 160-173.

Block, J., \& Robins, R. (1993). A longitudinal study of consistency and change in self-esteem from early adolescence to early adulthood. Child Development, 64, 909-923. 
Borghuis, J., Denissen, J. J. A., Oberski, D., Sijtsma, K., Meeus, W. H. J., Branje, S., Koot, H. M., \& Bleidorn, W. (2017). Big Five personality stability, change, and codevelopment across adolescence and early adulthood. Journal of Personality and Social Psychology, 113, 641-657.

Bouchard, T. J. Jr, \& Loehin, J. C. (2001). Genes, evolution, and personality. Behavior Genetics, 31, 243-273.

Branje, S. J. T., van Lieshout, C. F. M., \& Gerris, J. R. M. (2007). Big Five personality development in adolescence and adulthood. European Journal of Personality, 21, 45-62.

Bratko, D., Chamorro-Premuzic, T., \& Saks, Z. (2006). Personality and school performance: Incremental validity of self- and peer-rating over intelligence. Personality and Individual Differences, 41, 131-142.

Buhrmeister, D. (1990). Intimacy of friendship, interpersonal competence, and adjustment during preadolescence and adolescence. Child Development, 61, 1101-1111.

Cantin, S., \& Boivin, M. (2004). Change and stability in children's social network and self-perceptions during transition from elementary to junior high school. International Journal of Behavioral Development, 28, 561-570.

Catalano, R. F., Mazza, J. J., Harachi, T. W., Abbott, R. D., Haggert, K. P., \& Fleming, C. B. (2003). Raising healthy children through enhancing social development in elementary school: Results after 1.5 years. Journal of School Psychology, 41, 143-164.

Cieciuch, J. (2010). Pięcioczynnikowa struktura osobowości we wczesnej adolescencji [Five-factor structure of personality in early adolescence]. Studia Psychologica, 10, 251-271.

Costa, P. T., \& McCrae, R. R. (1988). Personality in adulthood: A six-year longitudinal study of selfreports and spouse ratings on the NEO Personality Inventory. Journal of Personality and Social Psychology, 54, 853-863.

Costa, P. T. Jr, \& McCrae, R. R. (1994). Revised NEO Personality Inventory (NEO-PI-R) and NEO-Five Factor Inventory (NEO-FFI). Professional Manual. Odessa, FL: Psychological Assessment Resources.

De Bolle, M., De Fruyt, F., McCrae, R. R., Löckenhoff, C. E., Costa, P. T. Jr, Aguilar-Vafaie, M. E., ..., \& Terracciano, A. (2015). The emergence of sex differences in personality traits in early adolescence: A cross-sectional, cross-cultural study. Journal of Personality and Social Psychology, 108, 171-185.

Del Barrio, V., Carrasco, M., \& Holgado, F. (2006). Factor structure invariance in the children's Big Five Questionnaire. European Journal of Psychological Assessment, 22, 158-167.

DeNeve, K. M., \& Cooper, H. (1998). The happy personality: a meta-analysis of 137 personality traits and subjective well-being. Psychological Bulletin, 124, 197-229.
Denissen, J. J. A., van Aken, M. A. G., Penke, L., \& Wood, D. (2013). Self-regulation underlies temperament and personality: An integrative developmental framework. Child Development Perspectives, 7, 255-260.

Digman, J. M. (1997). Higher-order factors of the Big Five. Journal of Personality and Social Psychology, 73, 1246-1256.

Dudzikowa, M., \& Wawrzyniak-Beszterda, R. (2010). Doświadczenia szkolne pierwszego rocznika reformy edukacji. Studium teoretyczno-empiryczne [School experience of the first year of education reform. A theoretical and empirical study]. Kraków: Impuls.

Erickson, E. H. (1968). Identity youth and crisis. New York: Norton and Company.

Graziano, W. G., \& Ward, D. (1992). Probing the Big Five in adolescence: Personality and adjustment during a developmental transition. Journal of Personality, 60, 425-439.

Heaven, P. C. L., \& Ciarrochi, J. (2012). When IQ is not everything: Intelligence, personality and academic performance at school. Personality and Individual Differences, 53, 518-522.

Hornowska, E., \& Paluchowski, W. J. (1991). Metodologiczne podstawy badań sekwencyjnych w ujęciu Schaiego i Baltesa [Methodological bases for sequential studies according to Schaie and Baltes]. Zeszyty Naukowe Wyższej Szkoty Pedagogicznej w Bydgoszczy, 8, 105-117.

Jansi, A. M., \& Anbazhagan, D. S. (2017). The relationship between big 5 personality traits and life satisfaction of among NCC women students. International Journal of Management, 8, 106-111.

John, O. P., Caspi, A., Robins, R. W., Moffitt, T. E., \& Stouthamer-Loeber, M. (1994). The "Little Five": Exploring the nomological network of the FiveFactor model of personality in adolescent boys. Child Development, 65, 160-178.

Keefe, K., \& Berndt, T. J. (1996). Relations of friendship quality to self-esteem in early adolescence. The Journal of Early Adolescence, 16, 110-129.

Keehn, J. D. (1982). The ethics of psychological research. Oxford, New York, Toronto, Sidney, Paris, Frankfurt: Pergamon Press.

Koepke, S., \& Denissen, J. J. A. (2012). Dynamics of identity development and separation-individuation in parent-child relationships during adolescence and emerging adulthood - a conceptual integration. Developmental Review, 32, 67-88.

Kokkinos, C. M., \& Markos, A. (2015). The Big Five Questionnaire for Children (BFQ-C). Factorial invariance across sex and age in a Greek sample of preadolescents. European Journal of Psychological Assessment, 33, 1-5.

Korczyński, S. (2014). Stres edukacyjny gimnazjalistów [Academic strees in junior high school students]. Prace Naukowe Akademii im. Jana Długosza w Częstochowie, 16, 89-110. 
Kotrla Topić, M., Perković Kovačević, M., \& Mlačić, B. (2012). Relations of the Big-Five personality dimensions to autodestructive behavior in clinical and non-clinical adolescent populations. Croatian Medical Journal, 53, 450-460.

Kozina, A. (2017). The development of multiple domains of self-concept in late childhood and in early adolescence. Current Psychology, 3,1-8.

Kulas, H. (1996). Locus of control in adolescence: A longitudinal study. Adolescence, 31, 721-720.

Kulas, H. (1998). Rozwój poczucia kontroli u dzieci w wieku szkolnym [Development of locus of control in school-age children]. Psychologia Wychowawcza, 3, 219-228.

Leung, S. A. (2008). The Big Five career theories. In J. A. Athanasou \& R. Van Esbroeck (Eds.), International Handbook of Career Guidance (pp. 115-132). Berlin: Springer Science.

Lewicka-Zelent, A., \& Trojanowska, E. (2018). Psychospołeczne funkcjonowanie uczniów klas siódmych w zreformowanej szkole podstawowej w kontekście zdrowia psychicznego [Psycho-social functioning of students at seventh grade of reformed primary school in the context of mental health]. Annales Universitatis Mariae Curie-Skłodowska, 31, 123-144.

Luan, Z., Hutteman, Z., Denissen, J. J. A., Asendorpf, J. B., \& van Aken, M. A. G. (2017). Do you see my growth? Two longitudinal studies on personality development from childhood to young adulthood from multiple perspectives. Journal of Research in Personality, 67, 44-60.

Maćkiewicz, M., \& Cieciuch, J. (2012). Jak mierzyć cechy Wielkiej Piątki u dzieci? Prace nad Obrazkowym Pomiarem Cech Osobowości Dzieci (OPCO-D) [How to measure the Big Five traits in children? Works on Picture Based Personality Survey for Children (PBPS-C)]. Psychologia Rozwojowa, 17, 69-82.

Maćkiewicz, M., \& Cieciuch, J. (2016). Pictorial Personality Traits Questionnaire for Children (PPTQ-C) - A new measure of children's personality traits. Frontiers in Psychology, 7, 1-11.

Magnusson, D., \& Bergman, L. R. (Eds.). (1990). Data quality in longitudinal research. Cambridge: Cambridge University Press.

Marcionetti, J., \& Rossier, J. (2016). Global life satisfaction in adolescence: The role of personality traits, self-esteem, and self-efficacy. Journal of Individual Differences, 37, 135-144.

Markey, P. M., Markey, C. M., \& Tinsley, B. (2018). Children's behavioral manifestations of the Big Five-Factor model of personality. Personality and Social Psychology Bulletin, 30, 423-432.

McCrae, R. R., \& Costa, P. T. (1996). Toward a new generation of personality theories: Theoretical contexts for the Five-Factor model. In J. Wiggins (Ed.), The Five-Factor model of personality: Theo- retical perspectives (pp. 51-87). New York: Guilford Press.

McCrae, R. R., \& Costa, P. T. (1997). Conceptions and correlates of openness to experience. In R. Hogan, J. Johnson, \& S. Briggs (Eds.), Handbook of personality psychology (pp. 825-847). San Diego: Academic Press.

McCrae, R. R., \& Costa, P. T. (2003). Personality in adulthood: A Five-Factor theory perspective ( $2^{\text {nd }}$ ed.). New York: Guilford Press.

Mendolia, S., \& Walker, I. (2015). Youth unemployment and personality traits. IZA Journal of Labor Economics, 4, 1-26.

Miller, C. F., Kochel, K. P., Wheeler, L. A., Updegraff, K. A., Fabes, R. A., Martin, C. L., \& Hanish, L. D. (2017). The efficacy of a relationship building intervention in $5^{\text {th }}$ grade. Journal of School Psychology, 61, 75-88.

Musiał, D. (2007). Kształtowanie się tożsamości w adolescencji [Development of identity in adolescence]. In P. Francuz \& W. Otrębski (Eds.), Studia z psychologii w KUL [Psychology Studies in KUL] (Vol. 14, pp. 73-92). Lublin: Wydawnictwo KUL.

Noftle, E. E., \& Fleeson, W. (2010). Age differences in big five behavior averages and variabilities across the adult life span: Moving beyond retrospective, global summary accounts of personality. Psychology and Aging, 25, 95-107.

Obuchowska, I. (2006). Drogi dorastania. Psychologia rozwojowa okresu dorastania dla rodziców i wychowawców [The paths of growing up. Developmental psychology of adolescence for parents and educators]. Warszawa: WSiP.

Obuchowska, I. (2009). Adolescencja [Adolescence]. In B. Harwas-Napierała \& J. Trempała (Eds.), Psychologia rozwoju człowieka. Charakterystyka okresów życia człowieka [Psychology of human development. Characteristics of stages of the human life] (Vol. 2, pp. 163-201). Warszawa: Wydawnictwo Naukowe PWN.

Oleś, P. (2011). Psychologia człowieka dorostego [Psychology of an adult]. Warszawa: Wydawnictwo Naukowe PWN.

Olivier, M., \& Herve, M. (2015). The Big Five Questionnaire for Children (BFQ-C): A French validation on 8- to 14-year-old children. Personality and Individual Differences, 87, 55-58.

Pedersen, N. L., \& Reynolds, C. A. (2002). Stability and change in adult personality: Genetic and environmental components. European Journal of Personality, 16, 77-78.

Piaget, J. (2005). The Psychology of Intelligence. New York: Routledge.

Piotrowski, K., Ziółkowska, B., \& Wojciechowska, J. (2014). Rozwój nastolatka. Wczesna faza dorastania [Youth development. Early phase of adolescence]. In I. Brzezińska (Eds.), Niezbędnik dobrego nauczyciela. Rozwój w okresie dzieciństwa i dorastania [Handbook for teachers. Development in child- 
hood and adolescence] (Series I, Vol. 5, pp. 1-63). Warszawa: Instytut Badań Edukacyjnych.

Pullmann, H., Raudsepp, L., \& Allik, J. (2006). Stability and change in adolescents' personality: A longitudinal study. European Journal of Personality, 20, 447-459.

Roberts, B. W. (2007). Contextualizing personality psychology. Journal of Personality, 75, 1071-1082.

Roberts, B. W., \& DelVecchio, W. F. (2000). The rankorder consistency of personality traits from childhood to old age: A quantitative review of longitudinal studies. Psychological Bulletin, 126, 3-25.

Roberts, B. W., \& Mroczek, D. (2008). Personality trait change in adulthood. Current Directions in Psychological Science, 17, 31-35.

Roberts, B. W., Wood, D., \& Caspi, A. (2008). The development of personality traits in adulthood. Handbook of personality: Theory and research, 3, 375-398.

Shimotsukasa, T., Oshio, A., Tani, M., \& Yamaki, M. (2019). Big Five personality traits in inmates and normal adults in Japan. Personality and Individual Differences, 141, 81-85.

Siegler, R. S. (1998). Children's thinking. New York: Prentice Hall.

Smetana, J. G., Campione-Barr, N., \& Metzger, A. (2006). Adolescent development in interpersonal and societal contexts. Annual Review of Psychology, 57, 255-284.

Soto, C. J., \& Tackett, J. L. (2015). Personality traits in childhood and adolescence: Structure, development, and outcomes. Current Directions in Psychological Science, 24, 358-362.

Strelau, J. (2000). Temperament a stres. Temperament jako czynnik moderujący stresory, stan i skutki stresu oraz radzenie sobie ze stresem [Temperament and stress. Temperament as a factor that moderates stressors, the state and effects of stress, and coping with stress]. In I. Heszen-Niejodek \& Z. Ratajczak (Eds.), Cztowiek w sytuacji stresu. Problemy teoretyczne i metodologiczne [Man in stressful situation. Theoretical and methodological problems] (pp. 88-132). Katowice: Wydawnictwo Uniwersytetu Śląskiego.

Suldo, S. M., Minch, D. R., \& Hearon, B. V. (2015). Adolescent life-satisfaction and personality characteristics: Investigating relationships using a Five Factor model. Journal of Happiness Studies, 16, 965-983.

Tomaszek, K., \& Muchacka-Cymerman, A. (2018). Radzenie sobie ze stresem i patogenny wzór zachowania A jako predyktory wypalenia szkolnego uczniów [Coping with stress and pathogenic A type behavior pattern as predictors of burn-out of students]. Teraźniejszość - Człowiek - Edukacja, 21, 67-86.

Tomé, G., Gaspar de Matos, M., Simões, C., Camacho, I., \& Alves Diniz, J. (2012a). How can peer group influence the behavior of adolescents: Ex- planatory model. Global Journal of Health Science, 4, 26-35.

Tomé, G., Gaspar de Matos, M., Simões, C., Camacho, I., \& Alves Diniz, J. (2012b). Portuguese adolescents: the importance of parents and peer groups in positive health. Spanish Journal of Psychology, 15, 1315-1324.

Weber, M., \& Huebner, S. (2015). Early adolescents' personality and life satisfaction: A closer look at global vs. domain-specific satisfaction. Personality and Individual Differences, 83, 31-36.

Williams, J. M., \& Currie, C. (2000). Self-esteem and physical development in early adolescence: $\mathrm{Pu}$ bertal timing and body image. The Journal of Early Adolescence, 20, 129-149.

Wortman, J., Lucas, R. E., \& Donnellan, M. B. (2012). Stability and change in the Big Five personality domains: Evidence from a longitudinal study in Australians. Psychology and Aging, 27, 867-874.

Zawadzki, B., Strelau, J., Szczepaniak, P., \& Śliwińska, M. (1998). Inwentarz Osobowości Paula T. Costy Jr i Roberta R. McCrae. Adaptacja polska [Personality Inventory by Paul T. Costa Jr and Robert R. McCrae. Polish adaptation]. Warszawa: Pracownia Testów Psychologicznych Polskiego Towarzystwa Psychologicznego. 